ДАРЕНСЬКИЙ О.М., д.т.н., професор, БУГАЄЦЬ Н.В., к.Т.н. (Український державний університет залізничного транспорту)

\title{
Застосування методу кінцевих елементів для визначення раціональних способів посилення рейкошпальної основи
}

В статті розглянуті можливі способи підвищення несучої здатності рейкошпальної основи колій незагального користування за рахунок посилення баластної призми і земляного полотна різними матеріалами, грунтуючись на аналізі досвіду вітчизняних і зарубіжних доріг.

Розглянуті розрахункові моделі рейкошпальної основи, які були побудовані із застосуванням методу кінцевих елементів, виконані як з посиленням їх за допомогою георешіток, геомембран, геотекстилю і інших матеріалів так $і$ без посилення.

Приведені максимальні розрахункові напруження в рейкошпальній основі під дією спеціального $i$ спеціалізованого рухомого складу, щзо має різні осьові навантаження.

Ключові слова: рейкошпальна основа, розрахункові напруження, посилення основи, земляне полотно, баластна призма.

\begin{abstract}
Вступ
Колії незагального користування $є$ важливою складовою транспортної системи України. Більше половини вантажів, що перевозяться магістральними дорогами, вантажиться на коліях незагального користування підприємств. Розгорнута довжина колій незагального користування перевищує 20 тис км. Використання в цій сфері ефективних i ресурсозберігаючих технологій $\mathrm{i}$ конструкцій може дати значний економічний ефект.
\end{abstract}

Постановка проблеми у загальному вигляді, її зв'язок $з$ важливими науковими та практичними завданнями

Досвід експлуатації колій
користування і дослідження, проведені науково-
дослідними і проектними організаціями, показали, що
для специфічних умов експлуатації колій незагального
користування (високі осьові навантаження, криві
малих радіусів, великі ухили) несуча здатність
рейкошпальної основи існуючих конструкцій верхньої
будови колії є недостатньою; це призводить до
швидкого накопичення залишкових деформацій,
розвитку несправностей, величина яких може швидко
перевищувати
допустимі

(C) О.М. Даренський, Н.В. Бугаєць, 2015
В умовах перевезення особливо небезпечних вантажів (розплавлених металів, шлаку, гарячих злитків сталі) такі несправності створюють загрозу для життя i здоров'я працівників підприємств, які знаходяться в безпосередньому контакті 3 технологічним рухомим складом. Такий стан справ ускладнюється ще й тим, що останнім часом на коліях незагального користування широко використовується конструкція ланкової колії на залізобетонних шпалах, жорсткість яких збільшує рівень динамічних дій і призводить до ще більшого розвитку несправностей.

Таким чином, підвищення несучої здатності рейкошпальної основи, яка включає баластний шар i земляне полотно, є важливим і актуальним завданням, вирішення якого має поліпшити стан колії, підвищити термін служби всіх ऑï конструктивних елементів, скоротити потребу в матеріалах, витрат праці і дати значний економічний ефект.

\section{Аналіз останніх досліджень і публікацій}

На підставі аналізу вітчизняного та закордонного досвіду, який зроблений в роботі [1], був зроблений висновок про те, що для умов колій незагального користування найдоцільнішими $\epsilon$ способи його посилення із застосуванням геотекстиля, геомембран, георешіток, шару щебенево - бітумної емульсії, щебенево - піщаного шару стабілізованого поліфілізаторами і їх комбінації (рис. 1).

Для визначення сфер застосування зазначених способів посилення рейкошпальної основи колій незагального користування були розроблені моделі і методи теоретичних досліджень його напруженого стану [2, 3, 4], зокрема була розроблена просторова модель з застосуванням методу кінцевих елементів [5] рис. 2. 
a)

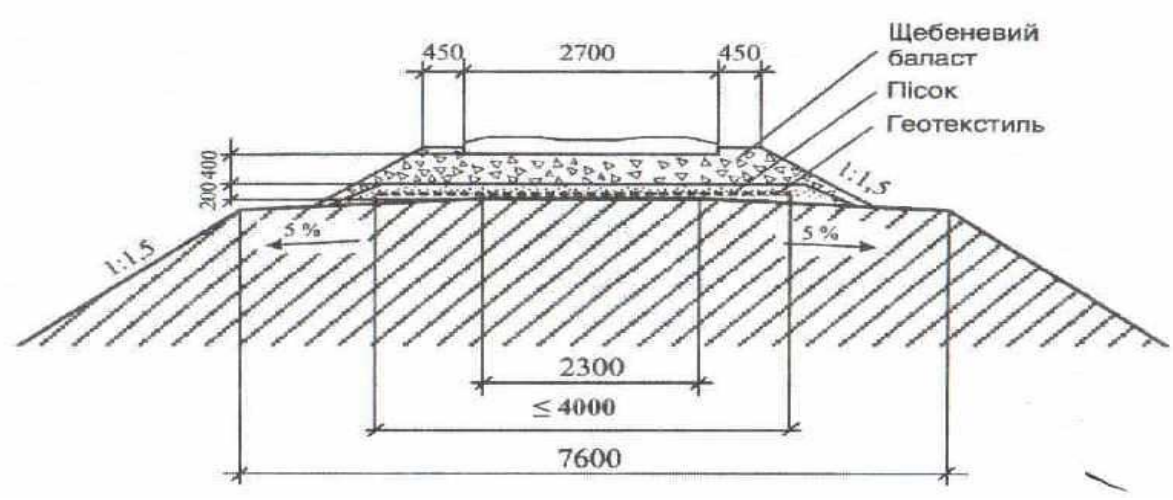

б)

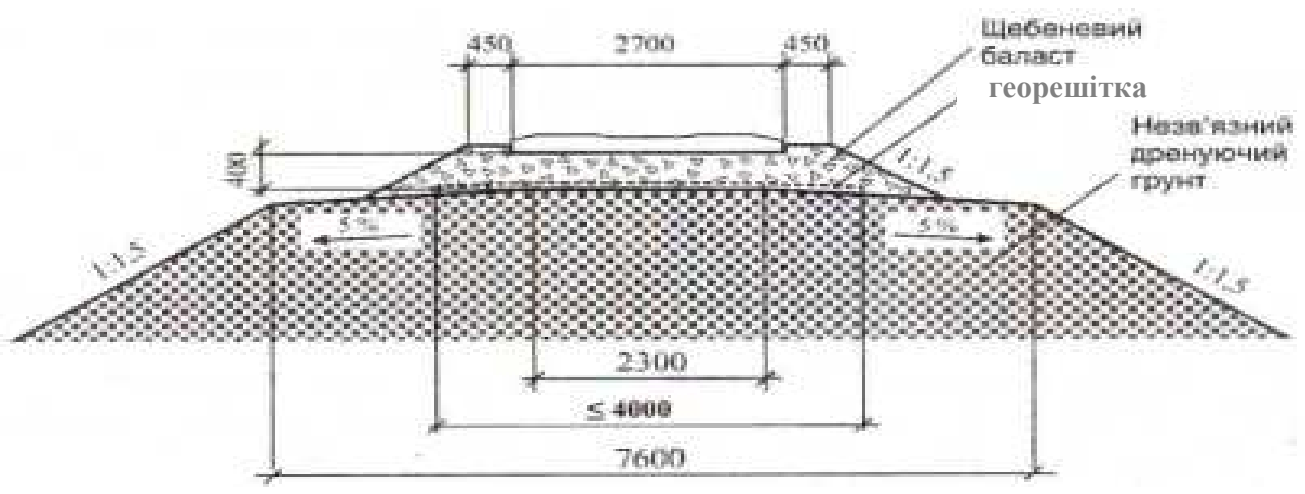

B)

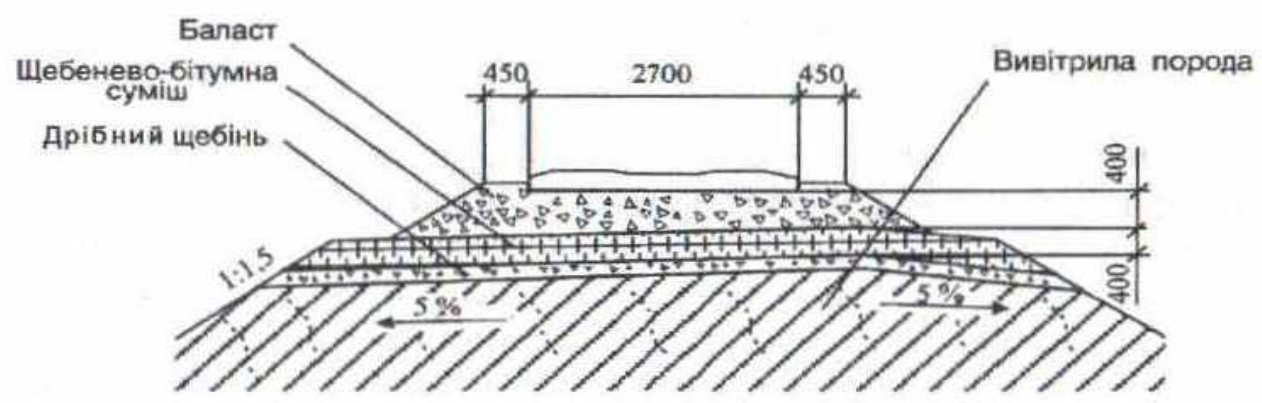

г)

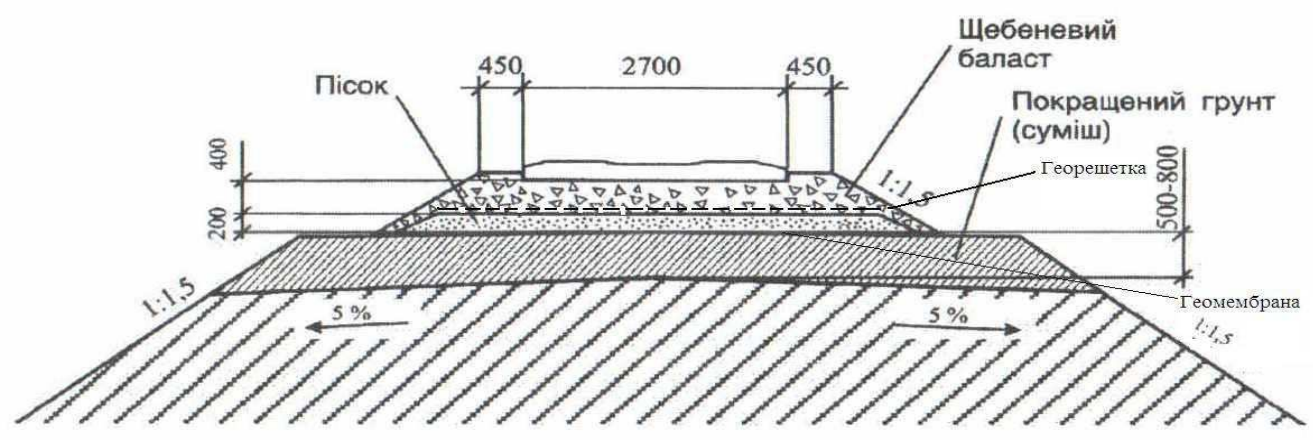

Рис. 1. Рекомендовані методи посилення рейкошпальної основи для колій незагального користування 

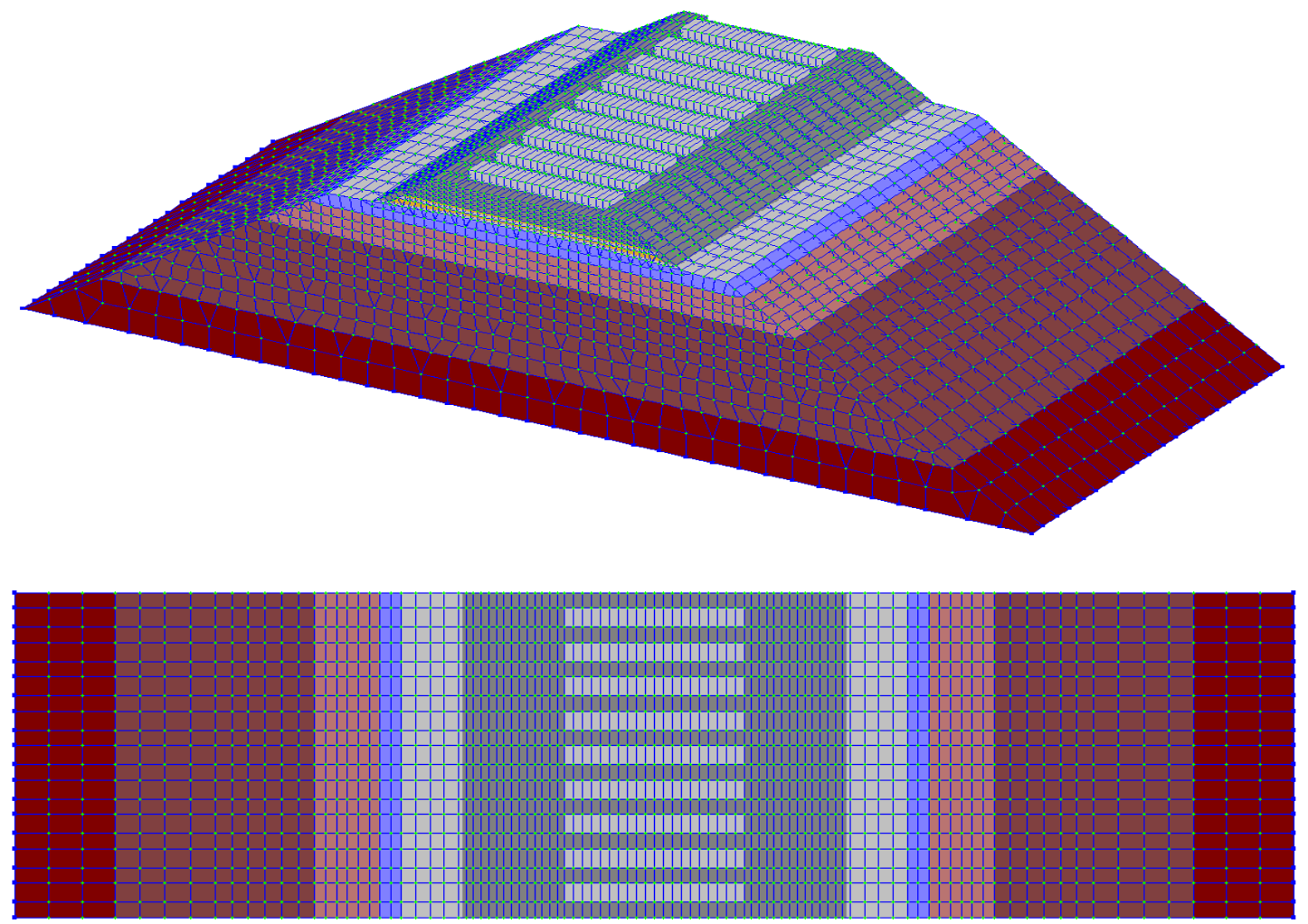

Рис. 2. Розрахункова модель рейкошпальної основи

\section{Основна частина}

Для встановлення особливостей напруженого стану рейкошпальної основи під дією спеціального і спеціалізованого рухомого складу залізниць незагального користування було виконано багатоваріантні чисельні дослідження як розрахункові були прийняті думпкари типу 6-ВС-60 3 осьовими навантаженнями $\quad \mathrm{P}_{\text {oc }}=216 \mathrm{\kappa H}, \quad$ чавуновози вантажопідйомністю $80 \mathrm{~T} \quad\left(\mathrm{P}_{\text {oc }}=353 \mathrm{\kappa H}\right)$ та $140 \mathrm{~T}$ $\left(\mathrm{P}_{\mathrm{oc}}=637 \mathrm{\kappa H}\right)$, шлаково3 3 ємкістю ковша $11 \mathrm{~m}^{3}$ $\left(\mathrm{P}_{\text {oc }}=215 \mathrm{\kappa H}\right)$ та візок для ізложниць И-120-550 $\left(\mathrm{P}_{\mathrm{oc}}=485 \mathrm{\kappa H}\right)$.

Саме ці типи рухомого складу було обрано для виявлення напруженого стану рейкошпальної основи для всіх можливих умов експлуатації колій незагального користування.

В таблиці 1 наведено узагальнені результати розрахунків напружень в баласті та на поверхні основної площадки в перетині під шпалою та на поверхні основної площадки в середині прольоту між шпалами.

Розраховувались варіанти як без посилення рейкошпальної основи, так і посиленою геотекстилем, георешіткою, стабілізованим баластним шаром та комбінований варіанти.

Розрахунки показали, що для прийнятих екіпажів діючі максимальні напруження, як правило, значно
\end{abstract}

менше рекомендуємих допускаємих (табл. 1), для щебеневого i шлакового баласту i перевищують, в окремих випадках, допускаємі напруження, для гравійного баласту і піщано - гравійної суміші.

Проте, максимальні напруги на основній площадці земляного полотна, при осьових навантаженнях перевищуючих 300 кН, перевищують допустимі значення, для конструкцій колії без посилення рейкошпальної основи. Таким чином, можна зробити висновок про те, що теоретичними розрахунками встановлена основна причина недостатньої, у ряді випадків несучої здатності рейкошпальної основи колій незагального користування залізниць.

Розрахунки також показали, що посилення рейкошпальної основи геотекстилем, дає незначний ефект i може бути рекомендоване, тільки для поліпшення фільтруючих здібностей баласту і грунту.

Значно краще працює конструкція колії баластний шар якої посилений георешіткою, зниження діючих напружень на основній площадці може перевищувати $18 \%$. Укладання піщано - щебеневого шару стабілізованого бітумом або поліфілізаторами знижує діючі на основній площадці напруження на 25 - $32 \%$, проте в деяких випадках при високих осьових навантаженнях можливо деяке до $5 \%$ збільшення максимальних напружень за рахунок перерозподілів напружень і деформацій залізобетонних шпал. 
Найкращим чином показали себе комбіновані способи посилення укладанням стабілізуючого піщано - щебеневого шару 3 геомембраною на піщаній подушці і георешіткою в баластному шарі. Зниження напружень в цьому випадку може складати $30-35 \%$.

Таблиця 1

Максимальні розрахункові напруження в рейкошпальній основі (кПа)

\begin{tabular}{|c|c|c|c|c|c|c|c|c|c|c|c|c|c|c|c|}
\hline \multirow[b]{3}{*}{$\begin{array}{c}\text { Xарактеристики } \\
\text { основи }\end{array}$} & \multicolumn{15}{|c|}{ Тип рухомого скпаду } \\
\hline & \multicolumn{3}{|c|}{ Думпкар 60} & \multicolumn{3}{|c|}{ Чaвуновоз $140 \mathrm{~T}$} & \multicolumn{3}{|c|}{ 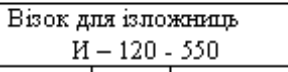 } & \multicolumn{3}{|c|}{ Чaвyнoвos $80 \mathrm{~T}$} & \multicolumn{3}{|c|}{ Шлаковоs $11 \mathrm{~m}^{3}$} \\
\hline & 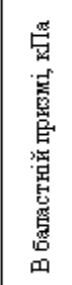 & 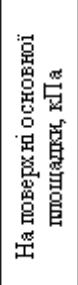 & 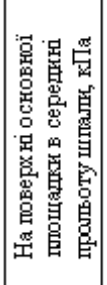 & 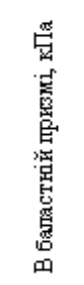 & 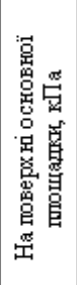 & 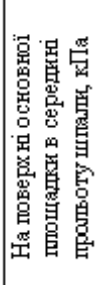 & 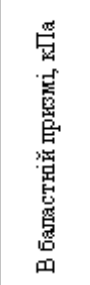 & 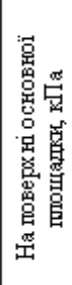 & 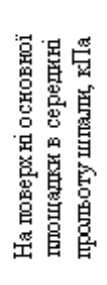 & 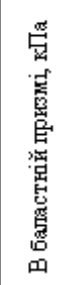 & 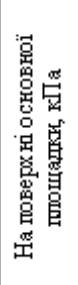 & 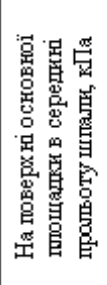 & 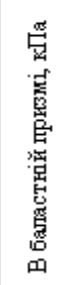 & 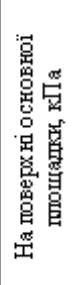 & 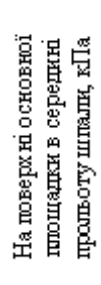 \\
\hline Без посипенна & $-61,9$ & $-40,8$ & $-35,8$ & $-113,5$ & $-66,2$ & $-55,8$ & -117 & $-66,5$ & $-56,3$ & $-89,1$ & $-53,5$ & $-45,1$ & $-57,7$ & $-38,2$ & $-32,5$ \\
\hline Геотекстипь & $-62,9$ & $-40,5$ & $-35,3$ & -113 & $-65,8$ & $-55,2$ & $-117,3$ & $-64,8$ & $-56,1$ & $-89,3$ & $-51,7$ & $-44,2$ & $-57,7$ & $-38,1$ & $-31,2$ \\
\hline Гeop emitka & $-74,3$ & $-35,4$ & $-32,1$ & -134 & $-55,1$ & $-48,7$ & -136 & $-54,6$ & $-47,4$ & -102 & $-45,9$ & $-40,5$ & $-69,1$ & $-32,8$ & $-27,6$ \\
\hline $\begin{array}{c}\text { Піщано - щебенева } \\
\text { суміш } 3 \text { бітумом }\end{array}$ & -62 & $-41,3$ & $-31,5$ & -112 & $-67,5$ & $-48,8$ & -116 & $-67,4$ & $-44,6$ & $-88,9$ & $-61,5$ & $-36,2$ & $-57,6$ & $-40,1$ & $-27,8$ \\
\hline $\begin{array}{l}\text { Піщано - щеб ен ева } \\
\text { сумші з полім ером }\end{array}$ & $-62,3$ & $-39,6$ & $-28,2$ & -112 & $-63,5$ & $-37,2$ & -115 & $-67,5$ & $-35,2$ & -88 & $-66,4$ & $-30,5$ & $-57,9$ & $-42,8$ & $-22,5$ \\
\hline $\begin{array}{c}\text { Георешітка }+ \\
\text { геомембрана }+ \\
\text { стабілізованй } \\
\text { Баластншй шар }\end{array}$ & $-71,4$ & $-29,2$ & $-28,7$ & -129 & $-49,3$ & $-43,7$ & -132 & $-49,2$ & $-41,3$ & $-97,2$ & $-43,3$ & $-33,2$ & $-66,1$ & $-29,5$ & $-24,6$ \\
\hline
\end{tabular}

Розрахунок конструкції колії із заглибленим баластом, посиленим георешіткою показав приблизно ті ж результати.

Для перевірки результатів теоретичних розрахунків напружень діючих в баластному шарі і на основній площадці земляного полотна були проведені спеціальні експериментальні роботи на ділянках під’їзних колій Харківського філіалу “Київ Дністровський МГПЗТ” для цього були закладені експериментальні ділянки протяжністю 6,25 км на одній 3 яких існувала стандартна конструкція баластної призми; на другій ділянці рейкошпальна основа була посилена георешіткою, а підбаластний шар пошарово просочений поліфілізаторами, після укладання посилюючих елементів щебеневий баласт був повернутий в колію, ущільнений і після цього експлуатувався напротязі 2 місяців для стабілізації баласту. На обох ділянках укладена ланкова колія із старогодними рейками типу Р65 на залізобетонних шпалах, вертикальний знос рейок - до 10 мм, бічний до 13 мм, шпали залізобетонні старопридатні. Для скорочення кількості впливаючих чинників ділянки були вибрані в середній частині ланки, вертикальні і горизонтальні нерівності були ліквідовані, колія знаходилася в технічно справному стані.

При проведенні експериментальних робіт по ділянці обертався спеціально сформований состав який складався 3 тепловоза ТГМ, двох думпкарів типу
6-ВС 60, двох платформ завантажених щебенем до вагової норми 211 і 216 кН на вісь відповідно. Значення осьових навантажень контролювалися на вагонних вагах підприємств. Експериментальні роботи проводилися при швидкостях руху експериментального складу 5, 10, 15 км/год (за даними швидкостеміра локомотива). Одержані результати були оброблені по загально прийнятій методиці i приведені в табл. 2.

В таблиці приведені середні значення, максимально зареєстровані і їх середньоквадратичні відхилення. Тут же приведені дані теоретичних розрахунків сил діючих на шпали, напруження в баласті глибиною 0,5 м і на основній площадці земляного полотна. Зіставлення даних теоретичних розрахунків і експериментів показало їх задовільну збіжність, розбіжність не перевищує, як правило, $15 \%$.

Проведені експериментальні роботи показали, що використані i запропоновані моделі i методи розрахунків адекватні процесу який відбувається в динамічній системі “екіпаж-колія" i моделі розробленої 3 використанням методу кінцевих елементів, для оцінки напружено-деформованого стану рейкошпальної основи. 


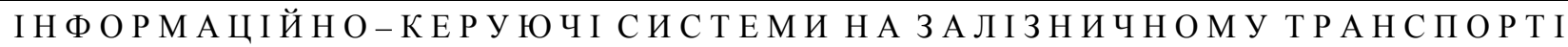

Таблиця 2

Зіставлення теоретичних і експериментальних значень силових параметрів

\begin{tabular}{|c|c|c|c|c|c|c|c|}
\hline \multirow{4}{*}{ Параметр } & & \multicolumn{6}{|c|}{ Tй рукомог о скпаду } \\
\hline & & \multicolumn{3}{|c|}{ Плат форта $\left(\mathrm{F}_{\mathrm{oc}}=211\right)$} & \multicolumn{3}{|c|}{ Дуршпар $6-\mathrm{BC}-60\left(\mathrm{P}_{\mathrm{ac}}=216\right)$} \\
\hline & & \multicolumn{6}{|c|}{ 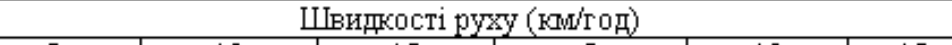 } \\
\hline & & 5 & 10 & 15 & 5 & 10 & 15 \\
\hline \multirow{4}{*}{$\begin{array}{c}\text { Навантаження на шпалу } \\
(\mathrm{kH})\end{array}$} & $\overline{P_{m}}$ & 41,9 & 43,4 & 46,4 & 44,0 & 47,6 & 52,4 \\
\hline & $P_{m w a x}$ & 52,3 & 53,8 & 55,8 & 57,3 & 62,4 & 66,0 \\
\hline & Cysadp. & 4,6 & 5,1 & 3,9 & 5,4 & 7,9 & 6,0 \\
\hline & Teop. ЗначенHя & 38,7 & 45,4 & 52,1 & 45,6 & 52,8 & 59,8 \\
\hline \multirow{4}{*}{$\begin{array}{l}\text { Напруження в баласті без } \\
\text { посипення основи (MПа) }\end{array}$} & $\bar{\sigma}_{\bar{b}}$ & 0,12 & 0,13 & 0,15 & 0,15 & 0,16 & 0,18 \\
\hline & $\sigma_{\overline{5} \operatorname{mw}}$ & 0,13 & 0,18 & 0,17 & 0,17 & 0,20 & 0,22 \\
\hline & $G$, Readp. & 0,012 & 0,000 & 0,008 & 0,015 & 0,016 & 0,0015 \\
\hline & Tеор. Значенна & 0,12 & 0,16 & 0,20 & 0,19 & 0,22 & 0,25 \\
\hline \multirow{4}{*}{$\begin{array}{l}\text { Напруження в баласті s } \\
\text { посипеною основою (МПа) }\end{array}$} & $\bar{\sigma}_{\bar{k}}$ & 0,11 & 0,12 & 0,14 & 0,14 & 0,17 & 0,18 \\
\hline & $\sigma_{\bar{B} \max }$ & 0,13 & 0,17 & 0,18 & 0,16 & 0,19 & 0,21 \\
\hline & $C_{y}$ Readp & 0,009 & 0,010 & 0,011 & 0,011 & 0,012 & 0,012 \\
\hline & Tеор. эначення & 0,12 & 0,15 & 0,21 & 0,15 & 0,21 & 0,22 \\
\hline \multirow{4}{*}{$\begin{array}{c}\text { Напруженна на основній } \\
\text { пПощапі беs поскпення } \\
\text { основн (WПа) }\end{array}$} & $\bar{\sigma}_{O N}$ & 0,042 & 0,048 & 0,054 & 0,045 & 0,053 & 0,056 \\
\hline & $\sigma_{O N \mathbb{M M}}$ & 0,052 & 0,057 & 0,061 & 0,049 & 0,057 & 0,064 \\
\hline & $C_{y} R g a d p$ & 0,004 & 0,005 & 0,005 & 0,005 & 0,006 & 0,006 \\
\hline & Teоp. Значенн & 0,0408 & 0,0551 & 0,0595 & 0,0479 & 0,0557 & 0,0576 \\
\hline \multirow{4}{*}{$\begin{array}{c}\text { Напруженна на основній } \\
\text { пПощаші з поснтенням } \\
\text { основи (МПа) }\end{array}$} & $\bar{\sigma}_{O M}$ & 0,027 & 0,034 & 0,039 & 0,032 & 0,036 & 0,039 \\
\hline & $\sigma_{\text {on } \max }$ & 0,032 & 0,039 & 0,043 & 0,036 & 0,040 & 0,043 \\
\hline & $C_{y}$ Rgadp & 0,002 & 0,002 & 0,003 & 0,003 & 0,003 & 0,003 \\
\hline & TEор ЗначенНА & 0,0275 & 0,0356 & 0,0401 & 0,0336 & 0,0374 & 0,0398 \\
\hline
\end{tabular}

Таблиця 3

Рекомендовані способи посилення рейкошпальної основи

\begin{tabular}{|c|c|c|c|c|c|c|c|}
\hline \multirow[b]{2}{*}{ 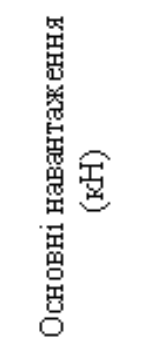 } & \multirow[b]{2}{*}{$\begin{array}{c}\text { Ван тажонапруженість } \\
\left(\frac{\text { sun.m.onopymmo }}{\text { nood }}\right)\end{array}$} & \multirow[b]{2}{*}{ 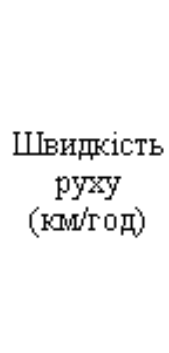 } & \multicolumn{5}{|c|}{ 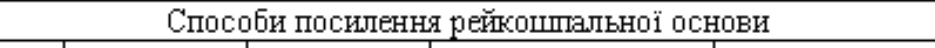 } \\
\hline & & & 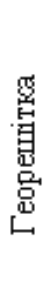 & 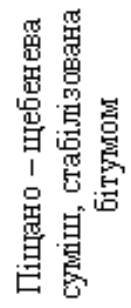 & 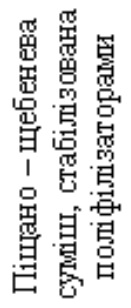 & 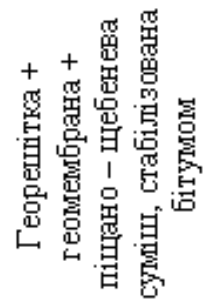 & 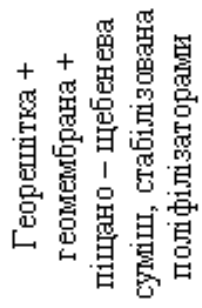 \\
\hline \multirow{9}{*}{$250-350$} & \multirow{3}{*}{$<10$} & $<10$ & + & & & & \\
\hline & & $10-20$ & + & & & & \\
\hline & & $20-40$ & + & & & & \\
\hline & \multirow{3}{*}{$10-15$} & $<5$ & + & + & & & \\
\hline & & $5-10$ & + & + & & & \\
\hline & & $10-20$ & + & + & + & & \\
\hline & \multirow{3}{*}{$>15$} & $<5$ & & + & + & + & \\
\hline & & $5-10$ & & + & + & + & \\
\hline & & $10-20$ & & + & + & + & + \\
\hline \multirow{2}{*}{$350-450$} & \multirow[b]{2}{*}{-} & $<5$ & & + & + & + & + \\
\hline & & $5-15$ & & + & + & + & + \\
\hline$>450$ & - & - & & & & + & + \\
\hline
\end{tabular}


Таким чином, на підставі даних теоретичних розрахунків експериментальних досліджень 3 урахуванням їх задовільної збіжності можна зробити висновки про те, що для умов промислових залізниць при обертанні рухомого складу 3 осьовими навантаженнями більше 300 кН несуча здатність традиційних конструкцій рейкошпальної основи $\epsilon$ недостатньою i вимагає посилення. В таблиці 3 приведені рекомендуємі способи посилення рейкошпальної основи, для ділянок які характеризуються не тільки значеннями осьових навантажень, але i швидкостями руху i вантажонапруженістю ділянок 3 урахуванням виконаних теоретичних i експериментальних досліджень. Такі рекомендації можна вважати обгрунтованими.

\section{Висновки \\ 1. Виконані багатоваріантні розрахунки просторових напружено - деформованих станів баласту і земляного полотна в різних експлуатаційних умовах колій незагального користування, при дії спеціальних і спеціалізованих вагонів. Розрахунки показали, що в умовах експлуатації колій незагального користування діючі напруження в щебеневому і шлаковому баласті, як правило, менше рекомендуємих допускаємих. Гравійний баласт i піщано - гравійна суміш не працездатні для умов промислового транспорту і не повинні застосовуватися при виконанні ремонтних робіт.}

2. При обертанні рухомого складу 3 осьовими навантаженнями більше 300 кН, несуча здатність грунтів земляного полотна явно недостатня i в цих випадках потрібне посилення рейкошпальної основи.

3. Розрахунки показали, що використовування геотекстиля і геомембран в умовах колій незагального користування малоефективне i може бути рекомендоване тільки для ділянок колії працюючих в умовах підвищеної вологості для посилення дренуючих здібностей баласту і грунту.

Використовування георешіток, піщано - щебеневих сумішей стабілізованих бітумом і поліфілізаторами, комбінованих варіантів значно знижує рівень напружень i може бути рекомендоване для використовування в умовах колій незагального користування.

\section{Список використаних джерел}

1. Бугаєць Н.В. Аналіз способів підвищення несучої здатності рейко - шпальної основи промислових залізниць [Текст] / Н. В. Бугаєць // Збірник наукових праць УкрДАЗТ. - 2007. - №87. - С.178184.

2. Коган А.Я. Колебания рельса при движении по нему переменной нагрузки [Текст] / А.Я. Коган // Вестник ВНИИЖТ.-1968.-№1.-С.7-12.
3. Даренський О.М. Розрахунок рейки як балки на пружних опорах під дією рухомого навантаження [Текст] / О.М. Даренський, Н.В. Бугаєць, В.Г. Витольберг // ДІІТ, тези доповідей. - 2010. C.171.

4. Даренський О.М. Визначення напруженого стану баласту в умовах металургійних підприємств [Текст] / О.М. Даренський, Н.В. Бугаєць, // УкрДАЗТ, тези доповідей. - 2013 - С.364.

5. Даренський О.М. Моделювання елементів верхньої будови колії методом кінцевих елементів [Текст] / О.М. Даренський, О.В. Лобяк, Н.В. Бугаєць, Л.Г. Волчок // Зб. наук. праць УкрДАЗТ. - 2011. - № 122. - С. 270 - 279.

Даренский А.Н., Бугаец Н.В. Применение метода конечных елементов для определения рациональных способов усиления рельсошпального основания. В статье рассмотрены возможные способы повышения несущей способности рельсошпального основания путей необщего пользования за счет усиления балластной призмы и земляного полотна различными материалами, основываясь на анализе опыта отечественных и зарубежных дорог.

Рассмотрены расчетные модели рельсошпального основания, которые были построены с применением метода конечных элементов, выполненные как с усилением их при помощи георешеток, геомембран, геотекстиля и других материалов так и без усиления.

Приведены максимальные расчетные напряжения в рельсошпальном основании под действием специального и специализированного подвижного состава, имеющего разные осевые нагрузки.

Ключевые слова: рельсошпальное основание, расчетные напряжения, усиление основания, земляное полотно, балластная призма.

Darenskiy A.N., Bugaec N.V. The application of finiteelement method to determine the shortcuts of rail and sleeper subgrade reinforcement. Possible ways to improve bearing capacity of rail and sleeper subgrade of private tracks at the expense of ballast section and road bed reinforcement by means of different materials on the basis of the analysis of experience of home and foreign roads have been considered.

The design models of rail- sleeper subgrade which were built using a finite-element method performed either with their reinforcement by means of geogrids, geomembranes, geotextiles and other materials or without reinforcement have been considered.

Maximum design stresses in rail-sleeper subgrade under the influence of special and specialized rolling stock, having different axial loads has been presented 
Generalized results of stress determinations in ballast and on the surface of the main set of a roadbed in a crosssection under a sleeper and on the surface of the main set in the midspan between sleepers have been given in the article.

The comparison of theoretical and experimental values of force characteristics is conducted and recommended methods of rail and sleeper reinforcement depending on traffic volume and axial loads have been presented on the basis of the obtained results.

Key words: rail-sleeper subgrade, design stresses, subgrade reinforcement, roadbed, ballast section.

Рецензент д.т.н., професор Плугін А. А. (УкрДУЗТ)

Поступила 16.06.20152.

Даренський Олександр Миколайович, д.т.н., професор кафедри «Колія та колійне господарство», Украӥнський державний університет залізничного транспорту, Харків, Україна.

Бугаєць Наталія Володимирівна, дочент кафедри «Колія та колійне господарство», Украӥнський державний університет залізничного транспорту, Харків, Украӥна.

Darenskiy Alexander Nikolaevich, Ph.D., Professor of Department "Road and Track acilities", Ukrainian State University of Railway Transport, Kharkiv, Ukraine.

Bugaec Natalya Vladimirovna, docent of Department "Road and Track acilities", Ukrainian State University Railway Transport, Kharkiv, Ukraine. 